\title{
CHEMOSPHERE
}

\section{Effects of cadmium and zinc on oxygen consumption, ammonium excretion, and osmoregulation of white shrimp (Litopenaeus vannamei)}

\author{
Jui Pin $\mathrm{Wu}^{\mathrm{a}}$, Hon-Cheng Chen ${ }^{\mathrm{a}, \mathrm{b}, *}$ \\ a Institute of Zoology, National Taiwan University, No. 1, Sec. 4, Roosevelt Road, Taipei 106, Taiwan, ROC \\ b Institute of Fisheries Sciences, National Taiwan University, Taipei 106, Taiwan, ROC
}

Received 27 October 2003; received in revised form 21 June 2004; accepted 13 July 2004

\begin{abstract}
White shrimp, Litopenaeus vannamei, a globally important cultured prawn species, is an ideal animal for studying the impairment caused by the effects of heavy metals that are often detected in coastal areas. The main purpose of the present study was to detect the acute toxicity of $\mathrm{Cd}$ and $\mathrm{Zn}$ to $\mathrm{L}$. vannamei, and to investigate their effects on gill functions, which have not been carried out in this species before, hoping to obtain some important significance. First of all, we examined the acute toxicity of cadmium $(\mathrm{Cd})$ and zinc $(\mathrm{Zn})$ to $L$. vannamei and obtained 24-, 48-, 72-, and 96-h medium lethal concentration $\left(\mathrm{LC}_{50}\right.$ ) values of $2.58,1.30,1.14$, and $1.07 \mathrm{mg} \mathrm{Cdl}^{-1}$ and $3.98,2.14,1.75$, and $1.35 \mathrm{mgZnl}^{-1}$, respectively. Furthermore, we also found that exposure of shrimp to $\mathrm{Cd}$ or $\mathrm{Zn}$ caused an inhibition in oxygen consumption of $91.3 \%$ and $75.9 \%$ lower than that of the control. However, after separate exposure to $\mathrm{Cd}$ or $\mathrm{Zn}$, elevations in ammonium excretion were obtained, which were $153.7 \%$ and $144.1 \%$, respectively, higher than the control. It is most likely that elevations in ammonium excretion were related to decreased osmotic pressure of shrimp blood. Finally, the distribution of $\mathrm{Cd}$ and $\mathrm{Zn}$ within gills was also determined.
\end{abstract}

(C) 2004 Elsevier Ltd. All rights reserved.

Keywords: Litopenaeus vannamei; Heavy metal; Oxygen consumption; Ammonium excretion; Osmotic pressure

\section{Introduction}

For most aquatic animals, the gills are very important organs for maintenance of life. In marine animals, gills are crucial for respiration, excretion, acid-base balance,

\footnotetext{
* Corresponding author. Address: Institute of Zoology, National Taiwan University, No. 1, Sec. 4, Roosevelt Road, Taipei 106, Taiwan, ROC. Tel.: +886 22363 0231x3324; fax: +886223636837.

E-mail addresses: rb5_wu@yahoo.com.tw (J.P. Wu), honcheng@ccms.ntu.edu.tw (H.-C. Chen).
}

and osmotic and ionic regulation (Soegianto et al., 1999a). It was reported in Penaeus japonicus that both respiratory tissues and osmoregulatory tissues were identified to be located within the branchial chamber that carry out their physiological functions when ambient water is drawn into the chamber (Soegianto et al., 1999a). Thus, compared to other parts of the body covered by crusts providing the first protection in crustaceans, gills are immediately exposed to the environment external to the body and are the first organs exposed to pollutants when ambient water is contaminated. 
White shrimp, Litopenaeus vannamei, geographically distributed in Central and South America (Paez-Osuna and Ruiz-Fernandez, 1995), is a globally important cultured prawn species. Shrimp farms are often located near the coast and draw seawater directly from coastal areas to use for rearing the shrimp. However, coastal seawater is often contaminated by many kinds of pollutants because of human activities (Chua, 1992; PaezOsuna and Tron-Mayen, 1996). Hence, the impacts of pollutants should be considered, not only on cultured shrimp individuals but also on the shrimp culture industries and human health.

Heavy metals are the most common pollutants appearing in many coastal areas worldwide. In unpolluted water, the average concentration of $\mathrm{Cd}$ is about $0.05 \mu \mathrm{gd} \mathrm{l}^{-1}$, while in coastal waters it tends to increase to over $0.1 \mu \mathrm{g} \mathrm{Cdl}^{-1}$ and even over $10 \mu \mathrm{gCdl}^{-1}$ in some areas due to anthropogenic input, local geological conditions, and human activities, according to reported data (Soegianto et al., 1999a). Likewise, Zn concentrations in coast water had also been detected as $4-800 \mu \mathrm{g} \mathrm{Zn}{ }^{-1}$ (Bryan, 1976). According to the reports from EPA/ ROC, $\mathrm{Cd}$ concentrations in seawater of Taiwan are $\mathrm{ND}-1.6 \mu \mathrm{gdl}^{-1}$ where ND means that the value is under detection limit, and $\mathrm{Zn}$ concentrations are ND$68.1 \mu \mathrm{gZnl}^{-1}$ (EPA/ROC, 2002). For aquatic animals, when exposed to heavy metals, gills are often the major entry site of the metals and act as a transient store for accumulated metals (Soegianto et al., 1999a). In addition, direct damage to gill structures and functions of aquatic animals caused by exposure to higher levels of heavy metals have also been widely studied, especially in fish (Skidmore, 1970; Brafield and Mathiessen, 1976; Cardeilhac et al., 1979; Oronsaye and Brafield, 1984). However, for prawns, only in P. japonicus have the effects of heavy metals on gill structures and functions been well studied (Bambang et al., 1995; Soegianto et al., 1999a,b), and relatively less so in other prawn species such as $P$. indicus (Chinni et al., 2000). Even though L. vannamei is a very important cultured prawn species, surprisingly few related investigations have been conducted on it to date.

The objective of this present study was, therefore, to estimate the acute toxicity of $\mathrm{Cd}$ and $\mathrm{Zn}$ on L. vannamei, and then to investigate the effects of these two heavy metals on gill functions, such as oxygen consumption, ammonium excretion, and osmoregulation. Distributions of these two metals within gill tissues of both control and treated animals were also examined.

\section{Materials and methods}

Litopenaeus vannamei postlarvae were obtained from a commercial hatchery located in Pingtung, southern Taiwan and maintained in our laboratory. During main- tenance, the postlarvae were acclimatized in seawater with the following water conditions: temperature $25^{\circ} \mathrm{C}$, salinity 15 s.p.u., DO $5.8-6.5 \mathrm{mgl}^{-1}$, pH 7.157.87, and Eh $32-152 \mu \mathrm{Scm}^{-1}$, under a 12:12-h light-dark regime with continuous water circulation and filtration in 50-1 glass tanks; and they were fed newly hatched Artemia sp. nauplii and commercial shrimp feed until they were used for the experiments.

Acute toxicity tests with water renewal were based on the Standard Guide for Conducting Acute Tests with Fishes (EPA/ROC, 1998). After acclimation for over 1 week, postlarvae of size-selected $L$. vannamei with a mean body weight of $7.13 \pm 2.13 \mathrm{mg}$ were divided into several groups for each metal. Each group contained 10 animals and was put in 1000-ml glass beakers with different metal concentrations. Concentrations used for acute toxicity estimation were $0,0.5,1,2,3,4,5$, and $8 \mathrm{mgCdl}^{-1}$ and $0,1,5,10,50$, and $100 \mathrm{mgZnl}^{-1}$. In order to maintain the metal concentration and decrease the toxicity caused by potentially poisonous metabolites excreted by animals themselves within the beakers (McMahon, 2001), seawater used in the bioassays within each container was changed and renewed daily after exposure. Three replications were carried out for each concentration. Survival was observed, dead individuals were removed, and mortality was recorded after 24 , 48,72 , and $96 \mathrm{~h}$. To calculate $\mathrm{LC}_{50}$ values, the mortality of each treatment was considered and processed using a Basic program from the probit analysis described by Finney (1971).

In the oxygen consumption and ammonium excretion experiments, juveniles of $L$. vannamei weighing $0.84 \pm$ $0.12 \mathrm{~g}$ were exposed to either $3 \mathrm{mgCdl}^{-1}$ or $3 \mathrm{mgZnl}^{-1}$. After $24 \mathrm{~h}$ of exposure, treated animals as well as control individuals were tested for oxygen consumed and ammonium excreted. Oxygen consumption examination was based on the method described by Chinni et al. (2000). After being weighed, animals were put into an oxygen-consumption detection bottle (WTW KF12, Weilheim, Germany) filled with seawater of the test concentration, with a micro-processor oximeter (WTW OXI196) connected to a $180-\mathrm{mm}$ dot-printing microrecorder (Yogogawa, 4176, Tokyo, Japan). Test seawater within the bottle had a salinity of 15 s.p.u, a dissolved oxygen (DO) content of $>7.0 \mathrm{mgl}^{-1}$, and was also filtered through a $0.45-\mu \mathrm{m}$-pore filter. Oxygen consumption $\left(\mathrm{QO}_{2}, \mathrm{mg} \mathrm{O}_{2} \mathrm{~g}^{-1} \mathrm{~min}^{-1}\right)$ was calculated as follows:

$\mathrm{QO}_{2}=\Delta \mathrm{ppm} \times 1 / \mathrm{BW} \times V \times 1 / t ;$

where $\mathrm{QO}_{2}$ is the amount of oxygen $(\Delta \mathrm{ppm})$ consumed in the interval t $(\mathrm{min}), \mathrm{BW}$ is the wet body weight $(\mathrm{g})$ of the individual, and $V$ was the volume (l) of the oxygen-consumption detection bottle. Detection of oxygen consumption was terminated only when the animal within the bottle had died of suffocation. Additionally, 
the seawater in the bottle was sampled at the beginning and end of the oxygen consumption analysis to determine the level of ammonium- $\mathrm{N}$ right away in order to factor in the transformation to nitrite or nitrate. Determination of ammonium-N within seawater was based on the phenolhypochlorite method (Solarzano, 1969). Ammonium-N excreted $\left(\mathrm{ENH}_{4}^{+}, \mu \mathrm{gNH}_{4}^{+} \mathrm{g}^{-1} \mathrm{~min}^{-1}\right)$ by animals was calculated as follows:

$\mathrm{ENH}_{4}^{+}=\Delta \mathrm{ppb} \times 1 / \mathrm{BW} \times V \times 1 / T ;$

where $\mathrm{ENH}_{4}^{+}$is the amount of ammonium $(\Delta \mathrm{ppb})$ generated in the total experimental time $T(\min )$.

For hemolymph sampling, juveniles of $L$. vannamei with body weights of $4.59 \pm 0.87 \mathrm{~g}$ were tested and sacrificed to measure osmotic pressure after acute exposure to each of the heavy metals. Animals were divided into three groups: one group was exposed to $3 \mathrm{mgCdl}^{-1}$ and one to $3 \mathrm{mg} \mathrm{Znl}^{-1}$ for $24 \mathrm{~h}$, while no metal was used for the control group. Each treatment contained 10 individuals and was run in triplicate. In all case, hemolymph was extracted by heart puncture using a $0.5-\mathrm{ml}$ syringe with no anticoagulant. The osmotic pressure of the hemolymph was immediately individually determined using a micro-osmometer $\left(20 \mu \mathrm{lsample}^{-1}\right)$ (Advanced Instrument, 3 MO-Plus, Norwood, MA, USA). After hemolymph sampling, gills of each shrimp were freshly dissected out to measure the concentrations of heavy metals. Gill tissues were dried for $24 \mathrm{~h}$ at $105^{\circ} \mathrm{C}$, and

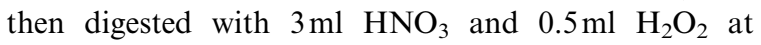
$95^{\circ} \mathrm{C}$. Metal concentrations of gills were measured by polarized Zeeman atomic absorption spectrophotometer
(Hitachi Model Z-8100, Tokyo, Japan) (EPA/ROC, 1994).

Statistical analysis was performed with one-way analysis of variance (ANOVA) to determine effects on oxygen consumption, ammonium- $\mathrm{N}$ excretion, and osmotic pressure after acute exposure to $\mathrm{Cd}$ or $\mathrm{Zn}$. Duncan's multiple-range test was used to evaluate the mean difference among individual groups at a 0.05 significance level.

\section{Results}

The percentage mortality of $L$. vannamei exposed to $\mathrm{Cd}$ and $\mathrm{Zn}$ in each 24-h interval is shown in Tables 1 and 2. No deaths of control animals were observed. The higher the concentration of metals the shrimp were exposed to, the higher mortality we observed. After $\mathrm{Cd}$ treatment, death became apparent at a concentration of $1 \mathrm{mgCdl}^{-1}$ in the first $24 \mathrm{~h}$. Mortality rates of $100 \%$ were observed after a 48 -h exposure to concentrations of 4,5 , and $8 \mathrm{mg} \mathrm{Cdl}^{-1}$. According to the mortalities recorded, the 24-, 48-, 72-, and 96- $\mathrm{h} \mathrm{LC}_{50}$ values were 2.58, $1.30,1.14$, and $1.07 \mathrm{mgCd}^{-1}$, respectively. Likewise, only $15 \%$ of the average mortality was observed during the first $24 \mathrm{~h}$ after animals were exposed to $1 \mathrm{mg} \mathrm{Znl}^{-1}$ (Table 2), while $100 \%$ mortality rates during the first $24 \mathrm{~h}$ was recorded when animals were exposed to concentrations higher than $50 \mathrm{mgZnl}^{-1}$. The 24-, 48-, 72-, and 96-h $\mathrm{LC}_{50}$ values obtained were $3.98,2.14,1.75$, and $1.35 \mathrm{mgZn1}^{-1}$, respectively.

Table 1

Percentage mortality (\%) of L. vannamei exposed to various cadmium concentrations for $96 \mathrm{~h}$ and its medium lethal concentration ( $\mathrm{LC}_{50}$ with $95 \%$ confidence limits) calculated by probit analysis

\begin{tabular}{|c|c|c|c|c|c|c|c|c|}
\hline \multirow{2}{*}{$\begin{array}{l}\text { Exposure } \\
\text { time (h) }\end{array}$} & \multicolumn{7}{|c|}{ Cadmium concentration $\left(\mathrm{mg} \mathrm{Cd}^{-1}\right)$} & \multirow[t]{2}{*}{$\mathrm{LC}_{50}\left(\mathrm{mgCdl}^{-1}\right)$} \\
\hline & 0 & 0.5 & 1 & 2 & 4 & 5 & 8 & \\
\hline 24 & 0 & 0 & 10 & 50 & 75 & 80 & 80 & $2.58(2.28-2.93)$ \\
\hline 48 & 0 & 0 & 23 & 90 & 100 & 100 & 100 & $1.30(1.18-1.42)$ \\
\hline 72 & 0 & 0 & 30 & 100 & 100 & 100 & 100 & $1.14(1.07-1.21)$ \\
\hline 96 & 0 & 0 & 40 & 100 & 100 & 100 & 100 & $1.07(1.00-1.14)$ \\
\hline
\end{tabular}

Table 2

Percentage mortality (\%) of L. vannamei exposed to various zinc concentrations for $96 \mathrm{~h}$ and its medium lethal concentration $\left(\mathrm{LC}_{50}\right.$ with $95 \%$ confidence limits) calculated by probit analysis

\begin{tabular}{|c|c|c|c|c|c|c|c|}
\hline \multirow{2}{*}{$\begin{array}{l}\text { Exposure } \\
\text { time (h) }\end{array}$} & \multicolumn{6}{|c|}{ Zinc concentration $\left(\mathrm{mgZn} \mathrm{l}^{-1}\right)$} & \multirow[t]{2}{*}{$\mathrm{LC}_{50}\left(\mathrm{mgZnl}^{-1}\right)$} \\
\hline & 0 & 1 & 5 & 10 & 50 & 100 & \\
\hline 24 & 0 & 15 & 60 & 65 & 100 & 100 & $3.98(3.32-4.76)$ \\
\hline 48 & 0 & 15 & 85 & 100 & 100 & 100 & $2.14(1.85-2.47)$ \\
\hline 72 & 0 & 20 & 95 & 100 & 100 & 100 & $1.75(1.49-2.05)$ \\
\hline 96 & 0 & 35 & 95 & 100 & 100 & 100 & $1.35(1.12-1.62)$ \\
\hline
\end{tabular}




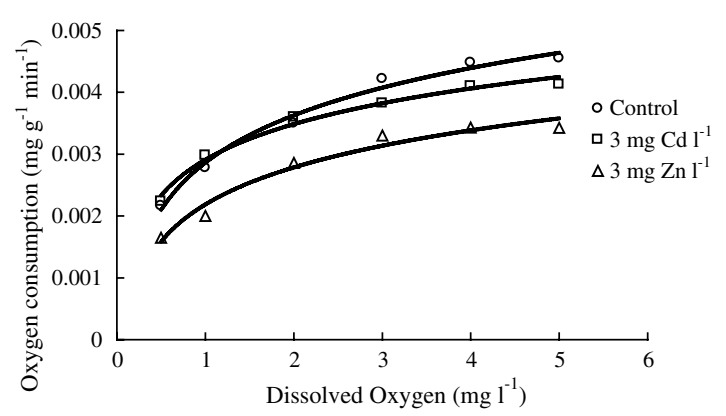

Fig. 1. Oxygen consumption of control L. vannamei $(\mathrm{O})$, as well as individuals exposed to $3 \mathrm{mgCdl}^{-1}(\square)$ and $3 \mathrm{mgZnl}^{-1}$ $(\triangle)$ for $24 \mathrm{~h}$, under different ambient dissolved oxygen concentrations. Regression curves fit mean values with $R$-square $\left(R^{2}\right)$ values of 0.988 in the control group, 0.985 in the Cd-treated group, and 0.968 in the $\mathrm{Zn}$-treated group.

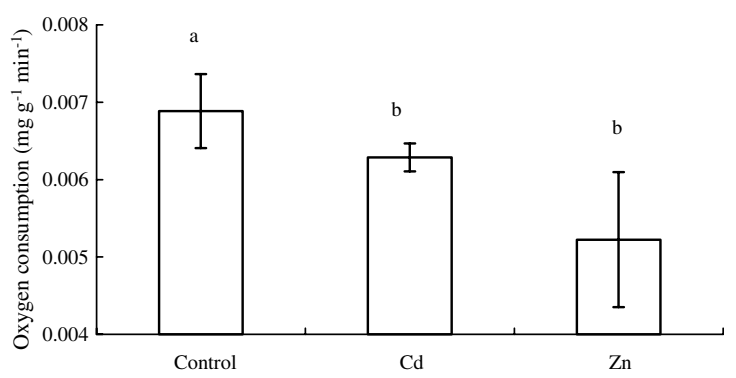

Fig. 2. Oxygen consumed (mean $\pm \mathrm{SE}$ ) by control L. vannamei, as well as individuals exposed to $3 \mathrm{mgCdl}^{-1}$ and $3 \mathrm{mgZnl}^{-1}$ for $24 \mathrm{~h}$ within the oxygen-consumption detection bottle with a dissolved oxygen detection electrode connected to a recorder during the first $4 \mathrm{~h}$ of recording time. Means with different letters significantly differ $(p<0.05)$.

Results in Figs. 1 and 2 clearly reveal inhibition effects on oxygen consumption caused by either $3 \mathrm{mgCdl}^{-1}$ or $3 \mathrm{mgZnl}^{-1}$, which are close to their 24-h $\mathrm{LC}_{50}$ values. Litopenaeus vannamei consumed different quantities of oxygen at different DO levels with higher amounts at higher DO concentrations. After exposure to either $3 \mathrm{mg} \mathrm{Cdl}^{-1}$ or $3 \mathrm{mgZnl}^{-1}$ for $24 \mathrm{~h}$, levels of oxygen consumed by treated $L$. vannamei were obviously lower than those of control individuals. During the first $4 \mathrm{~h}$ of the experiment, the average levels of oxygen consumed by $L$. vannamei treated with $3 \mathrm{mgCd}^{-1}$ or $3 \mathrm{mg} \mathrm{Zn1}^{-1}$ were $91.3 \%$ and $75.9 \%$ lower than that of the control, respectively (Fig. 2). However, unlike the inhibition on oxygen consumption, exposure to either $3 \mathrm{mgCdl}^{-1}$ or $3 \mathrm{mgZnl}^{-1}$ for $24 \mathrm{~h}$ caused elevations in the levels of ammonium excreted by L. vannamei (Fig. $3)$. After exposure for $24 \mathrm{~h}$, the average levels of ammonium excreted by $L$. vannamei treated with $3 \mathrm{mg} \mathrm{Cd1}^{-1}$ or $3 \mathrm{mgZn1} 1^{-1}$ were $153.7 \%$ and $144.1 \%$ higher compared to the average amount of the control animals.

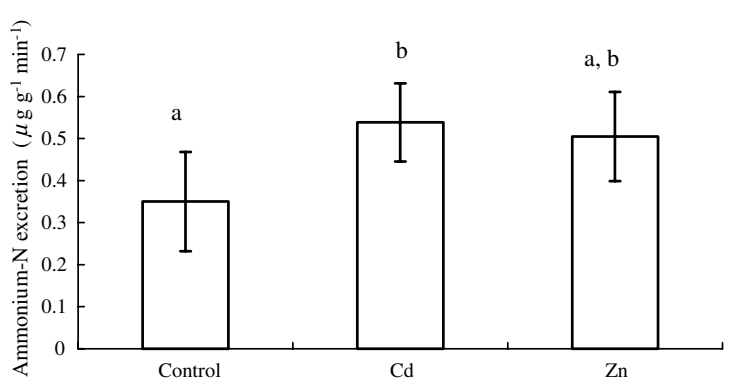

Fig. 3. Ammonium (mean $\pm \mathrm{SE}$ ) excreted by control $L$. vanna$m e i$, as well as individuals exposed to $3 \mathrm{mgCdl}^{-1}$ and $3 \mathrm{mgZnl}^{-1}$ for $24 \mathrm{~h}$ within the oxygen-consumption detection bottle with a dissolved oxygen detection electrode connected to a recorder during the entire recording time. Means with different letters significantly differ $(p<0.05)$.

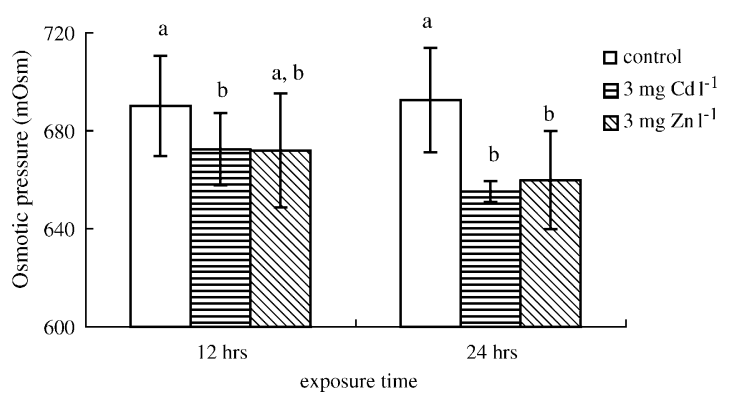

Fig. 4. Osmotic pressures (mean $\pm \mathrm{SE}$ ) of hemolymph of control Litopenaeus vannamei, as well as individuals exposed to $3 \mathrm{mgCdl}^{-1}$ and $3 \mathrm{mgZnl}^{-1}$ for 12 and $24 \mathrm{~h}$. Means with different letters significantly differ $(p<0.05)$.

Alterations in osmotic pressure of hemolymph in $L$. vannamei exposed to acute concentrations of $\mathrm{Cd}$ and $\mathrm{Zn}$ are shown in Fig. 4. After exposure for $12 \mathrm{~h}$, osmotic pressures of $L$. vannamei treated with $3 \mathrm{mgCdl}^{-1}$ or $3 \mathrm{mgZn1}^{-1}$ were $672.5 \pm 14.7$ and $672.0 \pm 23.3 \mathrm{mOsm}$ $\mathrm{kg}^{-1}$, respectively, both lower than that of control individuals at $690.1 \pm 20.5 \mathrm{mOsm} \mathrm{kg}^{-1}$. Furthermore, exposure for $24 \mathrm{~h}$ caused deeper effects in osmotic pressures of heavy metal-treated L. vannamei, with osmotic pressures of $655.3 \pm 4.2$ and $660.0 \pm 20.2 \mathrm{mOsm} \mathrm{kg}^{-1}$ in animals treated with $3 \mathrm{mgCd1}^{-1}$ or $3 \mathrm{mgZn1}^{-1}$, respectively, compared to $692.5 \pm 21.4 \mathrm{mOsm} \mathrm{kg}^{-1}$ in control individuals.

Results of the examination of concentrations of both metals within gill tissues of $L$. vannamei exposed to $3 \mathrm{mgCdl}^{-1}$ or $3 \mathrm{mgZnl}^{-1}$ for 12 and $24 \mathrm{~h}$ showed an easily identifiable time-dependence (Fig. 5). The $\mathrm{Cd}$ concentration within gills of Cd-treated individuals was $0.090 \pm 0.044 \mathrm{mg} \mathrm{g}^{-1}$ after $12 \mathrm{~h}$ and then increased to $0.153 \pm 0.056 \mathrm{mg} \mathrm{g}^{-1}$ after $24 \mathrm{~h}$, both of which were significantly higher than values for the control (Fig. 5A). Likewise, $\mathrm{Zn}$ concentrations within gills of L. van- 

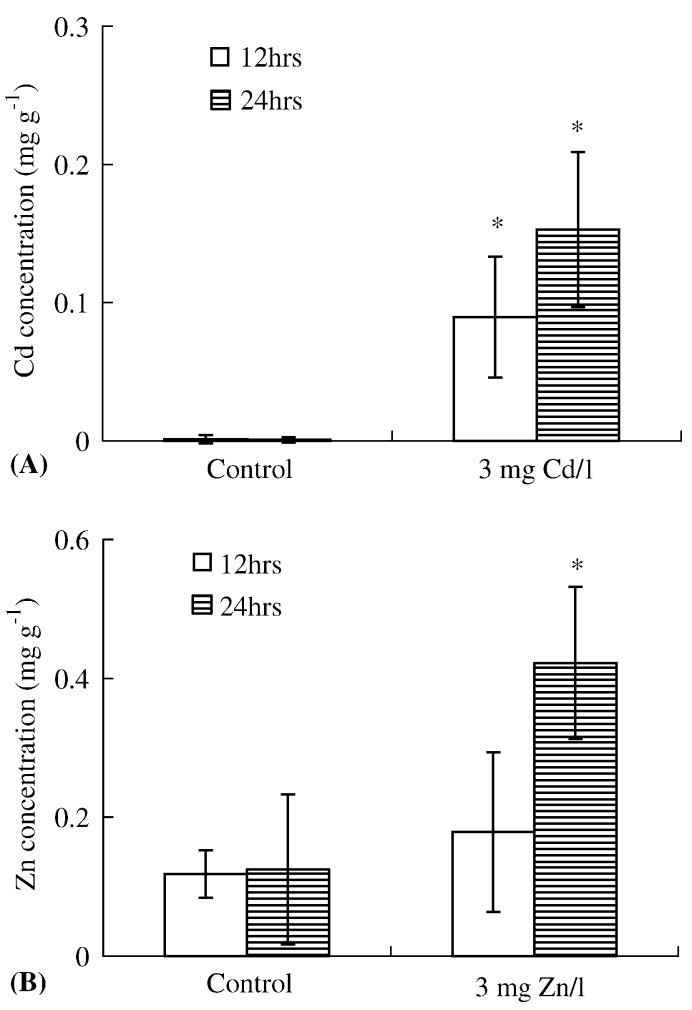

Fig. 5. (A) Cadmium (Cd) and (B) zinc ( $\mathrm{Zn})$ concentrations (mean $\pm \mathrm{SE}$ ) measured within gill tissues of $L$. vannamei after animals were exposed to either $3 \mathrm{mgCd}^{-1}$ or $3 \mathrm{mgZnl}^{-1}$ for 12 and $24 \mathrm{~h}$. Mean values of treated groups with an asterisk $\left(^{*}\right)$ significantly differ from those of control groups $(p<0.05)$.

namei exposed to $\mathrm{Zn}$ for 12 and $24 \mathrm{~h}$ were found to be $0.179 \pm 0.070$ and $0.422 \pm 0.126 \mathrm{mgg}^{-1}$, respectively (Fig. 5B).

\section{Discussion}

Acute toxicity of $\mathrm{Cd}$ and $\mathrm{Zn}$ has been studied in several Decapod species. For example, 72-h $\mathrm{LC}_{50}$ values of $\mathrm{Cd}$ for larvae of Palaemon serratus and Maja squinado have been obtained as 1.68 and $0.158 \mathrm{mgCdl}^{-1}$ (Marino-Balsa et al., 2000). In addition, 96-h $\mathrm{LC}_{50}$ values of Cd for larvae of Cancer irroratus, C. magister, and Paragrapsus quadridentatus are $0.25,0.247$, and $0.49 \mathrm{mg} \mathrm{Cd1}^{-1}$, respectively (Banijts-Claus and Benijts, 1975; Ahsanullah and Arnott, 1978; Martin et al., 1981), for juvenile of $P$. setiferus being $0.99 \mathrm{mgCdl}^{-1}$ (Vanegas et al., 1997), and for adult of Scylla serrata being $18 \mathrm{mgCd}^{-1}$ (Krishnaja et al., 1987). Likewise, 96-h $\mathrm{LC}_{50}$ value of $\mathrm{Zn}$ for larvae of $P$. setiferus is $43.87 \mathrm{mgCdl}^{-1}$ (Vanegas et al., 1997). In aquatic organisms, sensitivity to heavy metals is related to the metal biological activity. In this study, Cd showed greater toxicity to $L$. vannamei than $\mathrm{Zn}$. Vanegas et al.
(1997) worked in another prawn species P. setiferus and discussed in their article that the greater toxicity of $\mathrm{Cd}$ might be expected since zinc is an essential metal that is regulated by decapod crustaceans, whereas $\mathrm{Cd}$ had no known biological function.

Frias-Espericueta et al. (2001) studied the acute toxicity in $\mathrm{Cd}$ to L. vannamei postlarvae and found that the 96-h $\mathrm{LC}_{50}$ obtained was $2.49 \mathrm{mg} \mathrm{Cdl}^{-1}$, which was twofold higher than the $1.07 \mathrm{mgCdl}^{-1}$ we obtained. This great difference might have been due to the high salinity (34s.p.u.) they used throughout their experiments. It seems Cd performs higher toxicities to $L$. vannamei at lower salinities. Actually, this also occurs in many aquatic organisms investigated, such as the blue crab Callinectes sapidus which has $96-\mathrm{h} \mathrm{LC}_{50}$ values of $0.32,4.70$, and $11.60 \mathrm{mgCd}^{-1}$ at the different salinities of 1,15 , and 35 s.p.u. (Frank and Robertson, 1979), and the seabass Lates calcarifer with 7-day $\mathrm{LC}_{50}$ values of $1.99,14.20$, and $19.00 \mathrm{mgCd}^{-1}$ at salinities of 5, 15, and 30 s.p.u. (Shazili, 1995). A similar trend was also apparent in the grass shrimp Palaemonetes pugio (Sunda et al., 1978), and those authors suggested that the protective effects of increased salinity could be explained by variations in $\mathrm{Cd}$ complexation to chloride ion $\left(\mathrm{Cl}^{-}\right)$and free $\mathrm{Cd}$ ion concentrations with changing salinities. Likewise, higher uptake and accumulation rates of heavy metals were also reported in the brine shrimp Artemia franciscana (Ronny et al., 1992), oyster Crassostrea virginica, and the soft shell clam Mya arenaria (Wright and Zamuda, 1987) at lower salinities. All these confirm that different environmental conditions can affect the toxicity of heavy metals even in the same organism, because any of a number of variables such as the total concentration of the metal, $\mathrm{pH}$, alkalinity, the concentration of natural chelators, the concentration of competing metals, and the presence of adsorptive surfaces can affect the concentration of free metal ions within the environment and thus affect the response of an organism to that particular metal (Sunda et al., 1978).

McMahon (2001), in a review of the responses of aquatic crustaceans in low ambient dissolved oxygen, mentioned that many crustaceans possess an excellent regulatory ability in their oxygen consumption patterns and thus were called oxygen regulators. Our experiments also obviously demonstrate that oxygen consumed by L. vannamei showed no linear conformation to ambient oxygen levels regardless of whether or not the shrimp were exposed to a heavy metal (Fig. 1). Despite their regulatory capability, the oxygen consumption rate was indeed inhibited after L. vannamei was exposed to high concentrations of $\mathrm{Cd}$ and $\mathrm{Zn}$ (Figs. 1 and 2). Similar results were also found in different shrimp species (Chinni et al., 2000, 2002).

The adverse effects on oxygen consumption after exposure to heavy metals in fish have been widely studied, and much work has focused on the dysfunction of gills due to cytological or structural alterations. In $\mathrm{Zn}$-exposed 
rainbow trout Salmo gairdneri, gill structural alterations, including destruction of gill epithelium as well as contraction of the blood space, are believed to cause death through the breakdown of several vital gill functions (Skidmore, 1970). Similarly, respiratory impairment in crustaceans due to exposure to heavy metals was also reviewed (Spicer and Weber, 1991), and it was concluded that oxygen consumption generally decreases when crustaceans are acutely exposed to heavy metals. In addition, after exposure to a sublethal concentration (1.44 ppm) of lead $(\mathrm{Pb})$ for 30 days, it was evident that $\mathrm{Pb}$ inhibits oxygen consumption in $P$. indicus; similar results have been obtained in other crustaceans studied (Chinni et al., 2000). Those authors assumed that cytological damage should be related to the decrease in oxygen consumption because the gills are most likely the first target of waterborne heavy metals, including thickening of branchial epithelium and deep changes in hemolymph patterns in the gills with a concomitant increase in vacuolization and reduced hemolymph spaces causing perfusion stagnation. Cytological and histological damage caused by heavy metal exposure in $P$. japonicus was also reported (Soegianto et al., 1999a,b). For example, an increased number of nephrocytes in gill filaments, a blackened appearance of the gills, necrosis of gill cells resulting in narrowed or obstructed hemolymphatic vessels, the appearance of a space between the cuticle and the epithelial cells which contains black electron-dense material, and even fragmentation of nuclei within gill cells could be observed when $P$. japonicus were exposed to different concentrations of $\mathrm{Cd}$ for 4 days. Thus, the main pathological effect on the respiratory system caused by waterborne essential metals like $\mathrm{Zn}$ is primarily internal hypoxia resulting from disruption of gill function, whilst more toxic metals such as $\mathrm{Cd}$ and $\mathrm{Hg}$ interfere with the respiratory system, including cellular respiration (Spicer and Weber, 1991; Koizumi et al., 1994).

Ammonium is one of the final products following catabolism principally of amino acids that might have an alimentary or muscular origin, depending on nutritional conditions (Mayzaud and Conover, 1988). In addition to being utilized as energy substrates and components of body structures, amino acids can be more important than ions in the maintenance of osmotic pressure in prawns such as P. setiferus (McFarland and Lee, 1963; Rosas et al., 1999). Normally, increases in ammonium excretion reflect an increase in catabolism of amino acids. However, when exposed to lethal concentrations of heavy metals, dysfunction of ammonium excretion control follows after gill damage, while the outflow of ammonium from the hemolymph to the ambient water results in higher concentrations of ammonium in the water and a lower osmotic pressure in the hemolymph, as we found in the present study. Chinni et al. (2000, 2002) found that ammonium excretion was inhibited in $P$. indicus postlarvae exposed to sublethal concentrations of lead. Although there is still no confirmed evidence, it is assumed that the decrease in ammonia- $\mathrm{N}$ excretion by $P$. indicus postlarvae in the presence of toxicants can be attributed to a reduction in the metabolic rate or to an interaction of lead with pathways for the production of ammonia-N. Differences with our present study may be due to the metals used and their concentrations, shrimp species used, and other abiotic factors such as salinity and temperature. However, much effort still needs to be devoted to determining the relationship between heavy metal exposure and ammonium excretion to verify these related questions.

$\mathrm{Zn}$ is a ubiquitous and nutritionally essential metal that is required for normal growth, development, and functioning of animal species. $\mathrm{Zn}$ plays the role of cofactor in more than 200 metalloenzymes, while also being a functional component of transcription factor proteins that contribute to gene expression and regulation. Furthermore, zinc also exerts significant influence on the nervous and immune systems, on optimal vitamin A metabolism, and on the normal calcification of bone (Klaassen, 2001). For aquatic crustaceans like $L$. vannamei, which obtain zinc from the diet and ambient water, cessation of zinc supplementation causes significant depression in tissue mineralization (Davis et al., 1992; Davis and Lawrence, 1993). On the contrary, Cd is a nonessential trace metal that is toxic to animals. Therefore, it is very reasonable to find $\mathrm{Zn}$ in gills of control L. vannamei, while $\mathrm{Cd}$ existed at a very minute or even undetectable level (Fig. 5). Although it appears from this present study that both $\mathrm{Cd}$ and $\mathrm{Zn}$ significantly accumulated in gills after acute exposure for $24 \mathrm{~h}$, their toxic actions differed, markedly with $\mathrm{Cd}$ being more toxic than $\mathrm{Zn}$. According to Hogstrand and Haux (1991) who reviewed the tissue distribution of some heavy metals, at the subcellular level, the majority of $\mathrm{Cd}$ is distributed in the cytosol and appears with metallothionein (MT), while $\mathrm{Zn}$ is present in the nuclei and mitochondria. Furthermore, although gills are not the organs in which $\mathrm{Cd}$ and $\mathrm{Zn}$ are primarily finally distributed, they are indeed a major entry site of metals and act as transient stores for accumulated metals (Soegianto et al., 1999a).

In conclusion, we determined the acute toxicities of $\mathrm{Cd}$ and $\mathrm{Zn}$ to $\mathrm{L}$. vannamei in the form of $\mathrm{LC}_{50}$ values. Also, after short-term acute exposure, effects of both heavy metals on oxygen consumption, ammonium excretion, osmotic pressure, and metal accumulation within gills of L. vannamei were also demonstrated. Results show that L. vannamei is a good test organism for studying heavy-metal pollution. Our future work will focus on both the acute effects of these heavy metals on $L$. vannamei at other biological levels such as histological and biochemical levels, and chronic effects on metabolism, molting, and growth rates which are also very important for the prawn culture industry. 


\section{Acknowledgments}

We are very grateful for the help of Mr. Jeng-tian Lin in Pingtung, southern Taiwan, who arranged a sufficient quantity of shrimp for all of the experiments.

\section{References}

Ahsanullah, M., Arnott, G.H., 1978. Acute toxicity of copper, cadmium and zinc to larvae of the crab Paragrapsus quadridentatus and implications for water quality criteria. Aust. J. Mar. Freshwater Res. 29, 1-8.

Bambang, Y., Thuet, P., Charmantier-Daures, M., Trilles, J.-P., Charmantier, G., 1995. Effect of copper on survival and osmoregulation of various developmental stages of the shrimp Penaeus japonicus. Aquat. Toxicol. 33, 125139.

Banijts-Claus, C., Benijts, P., 1975. Sublethal Effects of Toxic Chemical on Aquatic Animals. Elsevier, Amsterdam.

Brafield, A.E., Mathiessen, P., 1976. Oxygen consumption by sticklebacks (Gasterosteus aculeatus) exposed to zinc. J. Fish Biol. 9, 359-370.

Bryan, G.W., 1976. Heavy metal contamination in the sea. In: Johnston, R. (Ed.), Marine Pollution. Academic Press, New York, USA, pp. 185-302.

Cardeilhac, P.T., Simpson, C.F., Lovelock, R.L., Yosha, S.F., Calderwood, H.W., Gudat, J.C., 1979. Failure of osmoregulation with apparent potassium intoxication in marine teleosts: a primary toxic effect of copper. Aquaculture 17, 231-239.

Chinni, S., Khan, R.N., Yallapragada, P.R., 2000. Oxygen consumption, ammonia-N excretion, and metal accumulation in Penaeus indicus postlarvae exposed to lead. Bull. Environ. Contam. Toxicol. 64, 144-151.

Chinni, S., Khan, R.N., Yallapragada, P.R., 2002. Acute toxicity of lead on tolerance, oxygen consumption, ammonia-N excretion, and metal accumulation in Penaeus indicus postlarvae. Ecotox. Environ. Safe. 51, 79-84.

Chua, T.E., 1992. Coastal aquaculture development and the environment the role of coastal area management. Mar. Poll. Bull. 25, 98-103.

Davis, D.A., Lawrence, A.L., 1993. Evaluation of the dietary zinc requirement of Penaeus vannamei and effects of phytic acid on zinc and phosphorus bioavailability. J. World Aquacult. Soc. 24, 40-47.

Davis, D.A., Lawrence, A.L., Gatlin III, D.M., 1992. Mineral requirements of Penaeus vannamei: a preliminary examination of the dietary essentiality for thirteen minerals. J. World Aquacult. Soc. 23, 8-14.

EPA/ROC, 1994. Standard guide for acid digestion of shellfish by hot plate method. NIEA C303.02.T. Environmental Protection Administration of the Republic of China, Taipei, Taiwan (in Chinese).

EPA/ROC, 1998. Standard guide for conducting acute tests with fishes: static renewal test for common carp. NIEA B904.10B. Environmental Protection Administration of the Republic of China, Taipei, Taiwan (in Chinese).

EPA/ROC, 2002. Annual report of environmental water quality in Taiwan from January to December 2002. EPA
074910198. Environmental Protection Administration of the Republic of China, Taipei, Taiwan (in Chinese).

Finney, D.J., 1971. Probit Analysis, third ed. Cambridge University Press, London.

Frank, P.M., Robertson, P.B., 1979. The influence of salinity on toxicity of cadmium and chromium to the blue crab, Callinectes sapidus. Bull. Environ. Contam. Toxicol. 21, 74 78.

Frias-Espericueta, M.G., Voltolina, D., Osuna-Lopez, J.I., 2001. Acute toxicity of cadmium, mercury, and lead to whiteleg shrimp (Litopenaeus vannamei) postlarvae. Bull. Environ. Contam. Toxicol. 67, 580-586.

Hogstrand, C., Haux, C., 1991. Binding and detoxification of heavy metals in lower vertebrates with reference to metallothionein. Comp. Biochem. Physiol. 100C (1/2), 137141.

Klaassen, C.D., 2001. Toxicology, sixth ed. McGraw-Hill, New York.

Koizumi, T., Yokota, T., Shirakura, H., Tatsumoto, H., Susuki, K.T., 1994. Potential mechanism of cadmiuminduced cytotoxicity in rat hepatocytes: inhibitory action of cadmium on mitochondrial respiratory activity. Toxicology 92, 115-125.

Krishnaja, A.P., Rege, M.S., Joshi, A.G., 1987. Toxic effects of certain heavy metals $(\mathrm{Hg}, \mathrm{Cd}, \mathrm{Pb}, \mathrm{As}$, and $\mathrm{Se})$ on the intertidal crab Scylla serrata. Mar. Environ. Res. 21, 109119.

Marino-Balsa, J.C., Poza, E., Vazquez, E., Berras, R., 2000. Comparative toxicity of dissolved metals to early larval stages of Palaemon serratus, Maja squinado, and Homarus gammarus (Crustacea: Decapoda). Arch. Environ. Contam. Toxicol. 39, 345-351.

Martin, M., Osborn, K.E., Billig, P., Glickstein, N., 1981. Toxicities of ten metals to Crassostrea gigas and Mytilus edulis embryos and Cancer magister larvae. Mar. Poll. Bull. 12, 305-308.

Mayzaud, P., Conover, R.J., 1988. O:N atomic ratio as a tool to describe zooplankton metabolism. Mar. Ecol. Prog. Ser. 45, 289-302.

McFarland, W.N., Lee, B.D., 1963. Osmotic and ionic concentration of shrimp of the Texas coast. Bull. Mar. Sci. 13, 391-416.

McMahon, B.R., 2001. Respiratory and circulatory compensation to hypoxia in crustaceans. Respir. Physiol. 128, 349364.

Oronsaye, J.A.O., Brafield, A.E., 1984. The effects of dissolved cadmium on the chloride cells of the gills of the stickleback, Gasterosteus aculeatus. J. Fish Biol. 25, 253-258.

Paez-Osuna, F., Ruiz-Fernandez, C., 1995. Trace metals in the Mexican shrimp Penaeus vannamei from estuarine and marine environments. Environ. Pollut. 87, 243-247.

Paez-Osuna, F., Tron-Mayen, L., 1996. Concentration and distribution of heavy metals in tissues of wild and farmed shrimp Penaeus vannamei from the northwest coast of Mexico. Environ. Int. 22, 443-450.

Ronny, B., Eva, K., Marc, B., 1992. Effects of salinity on the uptake of cadmium by the brine shrimp Artemia francisana. Mar. Ecol. Prog. Ser. 84 (3), 245-254.

Rosas, C., Martinez, E., Gaxiola, G., Brito, R., Sanchez, A., Soto, L.A., 1999. The effect of dissolved oxygen and salinity 
on oxygen consumption, ammonia excretion and osmotic pressure of Penaeus setiferus juveniles. J. Exp. Mar. Biol. Ecol. 234, 41-57.

Shazili, N.A.M., 1995. Effects of salinity and pre-exposure on acute cadmium toxicity to seabass, Lates calcarifer. Bull. Environ. Contam. Toxicol. 54, 22-28.

Skidmore, J.F., 1970. Respiration and osmoregulation in rainbow trout with gills damaged by zinc sulphate. J. Exp. Biol. 52, 481-494.

Soegianto, A., Charmantier-Daures, M., Trilles, J.-P., Charmantier, G., 1999a. Impact of cadmium on the structure of gills and epipodites of the shrimp Penaeus japonicus. Aquat. Living Resour. 12 (1), 57-70.

Soegianto, A., Charmantier-Daures, M., Trilles, J.-P., Charmantier, G., 1999b. Impact of copper on the structure of gills and epipodites of the shrimp Penaeus japonicus. J. Crust. Biol. 19 (2), 209-223.
Solarzano, L., 1969. Determination of ammonia in natural waters by the phenolhypochlorite method. Limnol. Oceanogr. 14, 799-801.

Spicer, J.I., Weber, R.E., 1991. Respiratory impairment in crustaceans and mollusks due to exposure to heavy metals. Comp. Biochem. Physiol. 100C (3), 339-342.

Sunda, W.G., Engel, D.W., Thuotte, R.M., 1978. Effects of chemical speciation on toxicity of cadmium to grass shrimp, Palaemonetes pugio: importance of free cadmium ion. Environ. Sci. Technol. 12 (4), 409-413.

Vanegas, C., Espina, S., Bottelo, A.V., Villanueva, S., 1997. Acute toxicity and synergism of cadmium and zinc in white shrimp, Penaeus setiferus, juveniles. Bull. Environ. Contam. Toxicol. 58, 87-92.

Wright, D.A., Zamuda, C.D., 1987. Copper accumulation by two bivalve molluscs salinity effects is independent of cupric ion activity. Mar. Environ. Res. 23 (1), 1-14. 